\title{
Taxonomy of Producing Organism, and Production, Isolation, Physico-chemical Properties and Biological Activities of Cirratiomycin $\mathrm{A}$ and $\mathrm{B}^{\dagger}$
}

\author{
Teruaki Shiroza, Naoyuki Ebisawa, * Atsuko KoJima, \\ Keiko Furihata, Akira Shimazu, Toyoshige Endō,** \\ Haruo SETO and Noboru ŌTAKE \\ Institute of Applied Microbiology, The University of Tokyo, \\ Bunkyo-ku, Tokyo 113, Japan \\ Received January 29, 1982
}

\begin{abstract}
The new peptide antibiotics have been obtained from the culture filtrate of a streptomycete, strain 248-Sq2, isolated from a soil sample collected at Nagano Prefecture, Japan.

On the basis of taxonomic studies, the producing organisms is designated as Streptomyces cirratus. Two active principles are named cirratiomycin A and B.

These antibiotics exhibit a narrow range of activities against Lactobacillus casei and some strains of Streptococcus and Mycobacterium.
\end{abstract}

In our screening program for antifolic metabolites using Lactobacillus casei as a test organism grown on a synthetic medium with a limiting amount of folic acid, two peptide antibiotics, cirratiomycin A (1) and B (2), have been isolated from the culture filtrate of Streptomyces cirratus 248-Sq2. The present paper deals with the taxonomy of the strain 248-Sq2, and the production, isolation, physico-chemical properties and biological activities of the antibiotics. The structural elucidation of these antibiotics will be described in the following report. ${ }^{1)}$

Taxonomic studies of strain 248-Sq2

The cirratiomycin producing strain $248-\mathrm{Sq} 2$ was isolated from a soil sample collected at Norikura Highland, Nagano Prefecture, Japan. The characterization of the strain was performed by the methods of the International Streptomyces Project (ISP) ${ }^{2)}$ and Waksman. ${ }^{3)}$ Determination of the cell wall type was carried out by Becker et al ${ }^{4)}$ for an analysis of diaminopimelic acids $\left(\mathrm{A}_{2} \mathrm{pm}\right)$ and by Lechevalier and Lechevalier $^{5)}$ for sugars.

The strain produced long and branched vegetative mycelium on agar media but fragmented to coryneform cells in the broth media with shaking. The aerial mycelium formed clusters with monopodial branching on the short main stem. The spore chain was straight, belonging to the section Rectiflexibiles $(R F)$,

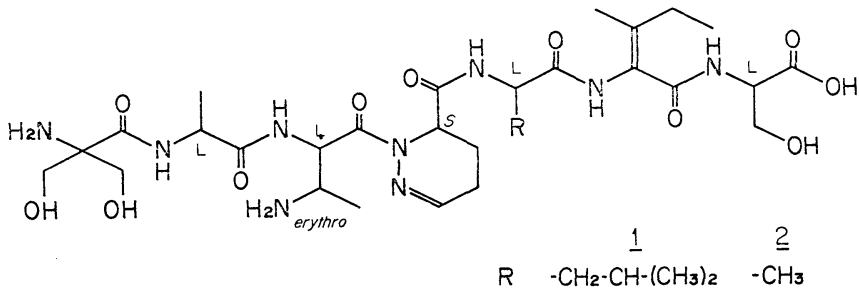

$\dagger$ Studies of Cirratiomycins. Part I.

* Present address: Research Institute, Meiji Milk Products, Co., Ltd., 1-21-3 Sakaemachi, Higashimurayama, Tokyo 189, Japan.

** Present address: Kyoritsu College of Pharmacy, 1-5-30 Shibakoen, Minato-ku, Tokyo 105, Japan. 


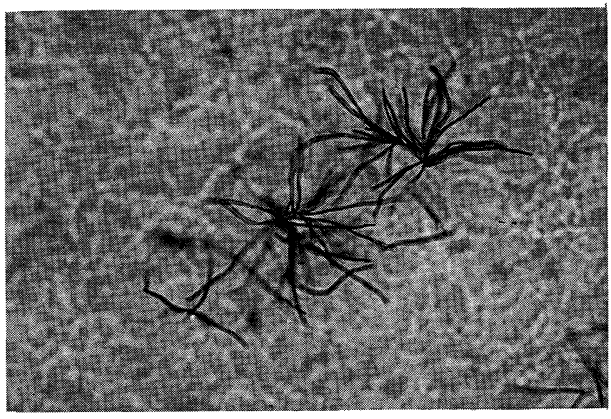

(a)

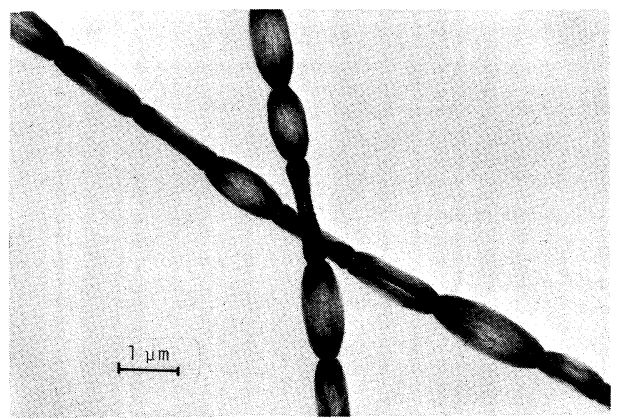

(c)

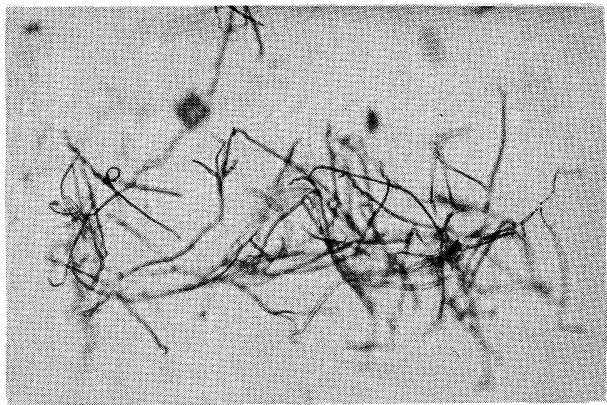

(b)

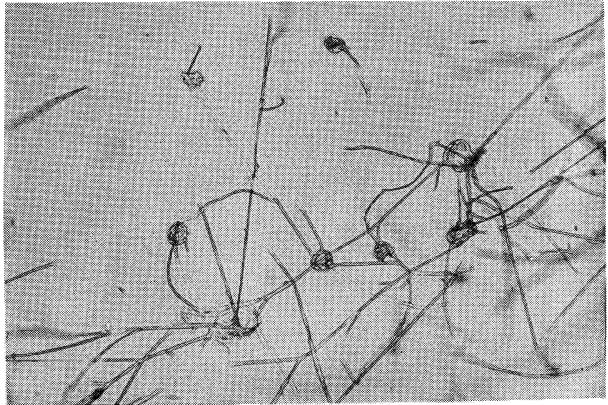

(d)

FIG. 1. Morphological Properties of Strain 248-Sq2.

(a) Straight spore chains on tyrosine agar, 4 weeks.

(b) Loops and hooks of spore chains on glucose-asparagine agar, 4 weeks.

(c) Smooth spores; electron micrograph after 4 weeks of culture on yeast extract-malt extract agar.

(d) Nest-like tangles in aerial hyphae on oatmeal agar, 4 weeks.

and rarely formed open loops and terminal hooks which are suggestive of Retinaculiaperti $(R A)$. The mature spore chains were generally long and had 10 to 50 or more spores per chain. Electron microscopy revealed that the mature spores were oval to cylindrical $(1.3 \sim 2.0$ by $0.6 \sim 0.8 \mu \mathrm{m})$ in shape with a smooth surface (Fig. 1a, b). The following special morphologies were also observed; long aerial hyphae which were entangled and the formation of knots and masses of spores on some agar media (Fig. 1c, d). The strain contained LL-A ${ }_{2} \mathrm{pm}$ but not sugars in its whole cell hydrolyzate, indicating the cell wall type as I.

The cultural and physiological characteristics of the strain are listed in Tables I and II, together with the utilization of carbon sources.
These characteristics can be summarized as follows; aerial mass color was of both Red and Gray color-series, the reverse side of the colony showed no distinctive pigments (colorless or pale yellow to dull yellow or yellowish brown) and soluble pigments (pale brown or pale yellowish brown) were formed in some media. The strain was mesophilic and possessed weak diastatic and proteolytic properties but did not form melanoid pigments.

From the above description the strain 248-Sq2 was considered to belong to the genus Streptomyces. Among the known Streptomyces species described in the 8 th edition of Bergey's Manual, ${ }^{6)}$ ISP reports ${ }^{7)}$ and any other publications listed in "Approved Lists of Bacterial Names", 8) the strain resembles Streptomyces cirratus and 
Table I. Cultural Characteristics of Strain 248-Sq2

\begin{tabular}{|c|c|c|c|}
\hline Media & Vegetative mycelium & Aerial mycelium & $\begin{array}{l}\text { Soluble } \\
\text { pigments }\end{array}$ \\
\hline $\begin{array}{c}\text { Sucrose nitrate agar } \\
\text { (Waks. No. 1) }\end{array}$ & Poor, colorless & $\begin{array}{l}\text { Poor, white to brownish } \\
\text { white; later became Gray ( } 5 \mathrm{fe})\end{array}$ & None \\
\hline $\begin{array}{l}\text { Glucose-asparagine agar } \\
\text { (Waks. No. 5) }\end{array}$ & $\begin{array}{l}\text { Moderate, pale yellowish } \\
\text { brown to light brown }\end{array}$ & $\begin{array}{l}\text { Abundant, Red (5dc) to } \\
\text { Gray ( } 7 \mathrm{fe})\end{array}$ & $\begin{array}{l}\text { Pale yellowish } \\
\text { orange }\end{array}$ \\
\hline $\begin{array}{l}\text { Glycerol-asparagine agar } \\
\text { (ISP No. 5) }\end{array}$ & $\begin{array}{l}\text { Poor, colorless to } \\
\text { pale yellow }\end{array}$ & None & None \\
\hline $\begin{array}{l}\text { Inorganic salt-starch agar } \\
\quad(\text { ISP No. 4) }\end{array}$ & $\begin{array}{l}\text { Moderate, colorless to } \\
\text { grayish yellow brown }\end{array}$ & $\begin{array}{l}\text { Abundant, Red (6ec-5dc) } \\
\text { to Gray }(7 \mathrm{fe}-5 \mathrm{fe})\end{array}$ & None \\
\hline $\begin{array}{l}\text { Tyrosine agar } \\
\text { (ISP No. 7) }\end{array}$ & Poor, brownish white & $\begin{array}{l}\text { None, later produced at } \\
\text { edge of colonies, white }\end{array}$ & $\begin{array}{l}\text { Brownish } \\
\text { white }\end{array}$ \\
\hline $\begin{array}{l}\text { Nutrient agar } \\
\qquad(\text { Waks. No. 14) }\end{array}$ & $\begin{array}{l}\text { Moderate, brownish white } \\
\text { to light yellow }\end{array}$ & None & None \\
\hline $\begin{array}{l}\text { Yeast extract-malt extract } \\
\text { agar (ISP No. 2) }\end{array}$ & Moderate, light brown & $\begin{array}{l}\text { Abundant, Red }(6 \mathrm{ec}-5 \mathrm{dc}) \\
\text { to Gray }(5 \mathrm{ef}-7 \mathrm{fe}-7 \mathrm{ih})\end{array}$ & $\begin{array}{l}\text { Pale yellowish } \\
\text { brown }\end{array}$ \\
\hline $\begin{array}{l}\text { Oatmeal agar } \\
\text { (ISP No. 3) }\end{array}$ & $\begin{array}{l}\text { Moderate, dull yellow } \\
\text { to yellowish brown }\end{array}$ & $\begin{array}{l}\text { Abundant, Red (6ec-5dc) } \\
\text { to Gray }(5 \mathrm{fe}-7 \mathrm{fe}-7 \mathrm{ih})\end{array}$ & $\begin{array}{l}\text { Pale yellowish } \\
\text { brown }\end{array}$ \\
\hline
\end{tabular}

Red, red color series; Gray, gray color series.

Table II. Physiological Properties of Strain 248-Sq2

\begin{tabular}{|c|c|}
\hline Temperature for growth & $10 \sim 37^{\circ} \mathrm{C}$ \\
\hline Optimum & $25 \sim 30^{\circ} \mathrm{C}$ \\
\hline \multicolumn{2}{|l|}{$\begin{array}{l}\text { Production of melanoid } \\
\text { pigments }\end{array}$} \\
\hline Tyrosine agar & Negative \\
\hline $\begin{array}{l}\text { Peptone-yeast extract } \\
\text { iron agar }\end{array}$ & Negative \\
\hline $\begin{array}{l}\text { Tryptone-yeast extract } \\
\text { broth }\end{array}$ & Negative \\
\hline Hydrolysis of starch & Positive (weak) \\
\hline Liquefaction of gelatin & Positive (weak) \\
\hline Peptonization of milk & Positive \\
\hline Coagulation of milk & Negative \\
\hline \multicolumn{2}{|l|}{ Utilization of carbon sources } \\
\hline Positive utilization & $\begin{array}{l}\text { D-Glucose, L-arabinose } \\
\text { D-xylose, D-fructose, } \\
\text { sucrose }\end{array}$ \\
\hline Doubtful utilization & L-Rhamnose, raffinose \\
\hline Negative utilization & D-Manitol, $i$-inositol \\
\hline
\end{tabular}

Streptomyces polychromogenes as shown in Table III. The spore chain morphology, $R F$ (a few $R A$ ), of the strain is different from $S$. cirratus, but $S$. polychromogenes. From our experience, however, it was observed that some strains which showed both $R F$ and $R A$ were affected in their expression rate of spore chain morphology by single colony isolation or by changing the culture conditions. Therefore, distinction of the strain by its spore chain morphology alone may be difficult in this case. On the other hand, the aerial mass color, Red to Gray color-series, of the strain is more similar to that of $S$. cirratus than $S$. polychromogenes. From these observations, it can be concluded that the strain is most closely related to $S$. cirratus. Although the strain had some different properties from $S$. cirratus, such as melanoid and soluble pigment formation which was also affected by single colony isolation, these were not sufficient to classify the strain as a new species. Thus, strain $248-\mathrm{Sq} 2$ was designated as $S$. cirratus Koshiyama, Okanishi, Ohmori, Miyaki, Tsukiura, Matsuzaki and Kawaguchi 1963 (Approved List No. 1, 1980). 
TABle III. Comparison of Strain 248-Sq2 with S. cirratus and $S$. polychromogenes

\begin{tabular}{|c|c|c|c|}
\hline & $248-\mathrm{Sq} 2$ & S. cirratus & S. polychromogenes \\
\hline Spore chain & $R F($ a few $R A)$ & $R A$ & $R F$ (a few $R A$ ) \\
\hline Spore surface & Smooth & Smooth & Smooth \\
\hline Special morphology & $\begin{array}{l}\text { Knots, nest-like tangles, } \\
\text { masses of spores }\end{array}$ & $\begin{array}{l}\text { Knots and moist, } \\
\text { nest-like tangles }\end{array}$ & $\begin{array}{l}\text { Knots, nest-like tangles } \\
\text { (some fragment into } \\
\text { spore-like bodies) }\end{array}$ \\
\hline Color of colony & Red and/or Gray & Red or Gray & Red or Blue* \\
\hline Color of reverse & Not distinct & Not distinct & Not distinct \\
\hline Melanoid pigments + & & PYIA, TYB, (TA) & PYIA, TYB, (TA) \\
\hline 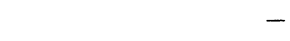 & PYIA, TYB, TA & (TA) & (TA) \\
\hline Soluble pigments & $\begin{array}{l}\text { NP or trace of yellowish } \\
\text { brown or brown }\end{array}$ & Yellow & NP or trace of yellow \\
\hline Carbon utilization + & $\mathrm{G}, \mathrm{A}, \mathrm{X}, \mathrm{F}, \mathrm{S}$ & $\mathrm{G}, \mathrm{A}, \mathrm{X}, \mathrm{F}, \mathrm{S}$ & $\mathrm{G}, \mathrm{A}, \mathrm{X}, \mathrm{F}, \mathrm{S}$ \\
\hline \pm or - & $\mathrm{I}, \mathrm{M}, \mathrm{Rh}, \mathrm{Ra}$ & $\mathrm{I}, \mathrm{M}, \mathrm{Rh}, \mathrm{Ra}$ & $\mathrm{I}, \mathrm{M}, \mathrm{Rh}, \mathrm{Ra}$ \\
\hline
\end{tabular}

$R F$, rectiflexibiles; $R A$, retinaculiaperti; PYIA, pepton-yeast extract iron agar; TYB, trypton-yeast extract broth; TA, tyrosine agar; NP, no pigment; G, D-glucose; A, arabinose; X, D-xylose; F, D-fructose; S, sucrose; I, $i$ inositol; M, D-mannitol; Rh, rhamnose; Ra, raffinose.

* Blue color-series in Bergey's Manual.

Table IV. Composition of the Assay Medium (1 liter)

\begin{tabular}{lclc}
\hline Casamino acid & $4.5 \mathrm{mg}$ & Pyridoxal & $1 \mathrm{mg}$ \\
Glucose & $20 \mathrm{~g}$ & Biotin & $0.01 \mathrm{mg}$ \\
Sodium acetate & $20 \mathrm{~g}$ & $p$-Aminobenzoic acid & $0.2 \mathrm{mg}$ \\
L-Cystine & $100 \mathrm{mg}$ & $\mathrm{K}_{2} \mathrm{HPO}_{4}$ & $500 \mathrm{mg}$ \\
L-Tryptophan & $100 \mathrm{mg}$ & $\mathrm{KH}_{2} \mathrm{PO}_{4}$ & $500 \mathrm{mg}$ \\
L-Glutamic acid & $100 \mathrm{mg}$ & $\mathrm{MgSO}_{4} \cdot 7 \mathrm{H}_{2} \mathrm{O}$ & $200 \mathrm{mg}$ \\
L-Arginine & $100 \mathrm{mg}$ & $\mathrm{NaCl}$ & $10 \mathrm{mg}$ \\
Thiamine & $1 \mathrm{mg}$ & $\mathrm{FeSO}_{4} \cdot 7 \mathrm{H}_{2} \mathrm{O}$ & $10 \mathrm{mg}$ \\
Riboflavin & $1 \mathrm{mg}$ & $\mathrm{MnSO}_{4} \cdot 4 \mathrm{H}_{2} \mathrm{O}$ & $10 \mathrm{mg}$ \\
Nicotinic acid & $1 \mathrm{mg}$ & Agar & $10 \mathrm{~g}$ \\
Pantothenic acid & $1 \mathrm{mg}$ & & \\
\hline
\end{tabular}

Table V. Physico-chemical Properties of Cirratiomycins

\begin{tabular}{|c|c|c|c|c|c|}
\hline & & \multicolumn{2}{|c|}{ Cirratiomycin A } & \multicolumn{2}{|c|}{ Cirratiomycin B } \\
\hline Appearence & & \multicolumn{4}{|c|}{ Amorphous white powder } \\
\hline M.P. & & \multicolumn{2}{|c|}{$220^{\circ} \mathrm{C}$ (dec. $)$} & \multicolumn{2}{|c|}{$215^{\circ} \mathrm{C}(\mathrm{dec})}$. \\
\hline $\mathrm{p} K \mathrm{a}^{\prime}$ & & \multicolumn{2}{|c|}{$3.4,6.7,8.8$} & \multicolumn{2}{|c|}{$3.4,6.4,8.5$} \\
\hline FD mass & & \multicolumn{2}{|c|}{$728(\mathrm{M}+\mathrm{H})^{+}, 750(\mathrm{M}+\mathrm{Na})^{+}$} & \multicolumn{2}{|c|}{$686(\mathrm{M}+\mathrm{H})^{+}, 708(\mathrm{M}+\mathrm{Na})^{+}$} \\
\hline Mol. form. & & \multicolumn{2}{|c|}{$\mathrm{C}_{31} \mathrm{H}_{53} \mathrm{~N}_{9} \mathrm{O}_{11} \cdot \mathrm{HCl}$} & \multicolumn{2}{|c|}{$\mathrm{C}_{28} \mathrm{H}_{47} \mathrm{~N}_{9} \mathrm{O}_{11} \cdot \mathrm{HCl}$} \\
\hline Elemental & & Calcd. $\%$ & Found $\%$ & Calcd. $\%$ & Found $\%$ \\
\hline \multirow[t]{5}{*}{ Analysis } & $\mathrm{C}$ & 48.72 & 48.39 & 46.57 & 46.11 \\
\hline & $\mathbf{H}$ & 7.07 & 7.20 & 6.65 & 6.69 \\
\hline & $\mathbf{N}$ & 16.50 & 16.98 & 17.46 & 17.82 \\
\hline & $\mathrm{O}$ & 23.05 & 24.11 & 24.39 & 24.71 \\
\hline & $\mathrm{Cl}$ & 4.65 & 4.16 & 4.92 & 4.67 \\
\hline Ninhydrin & & \multicolumn{4}{|c|}{ Pale purple } \\
\hline \multirow[t]{2}{*}{ TLC* } & No. 1 & 0.26 & & 0.16 & \\
\hline & No. 2 & 0.75 & & 0.63 & \\
\hline
\end{tabular}

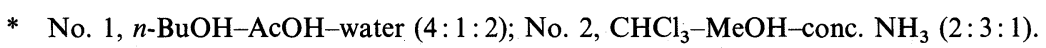




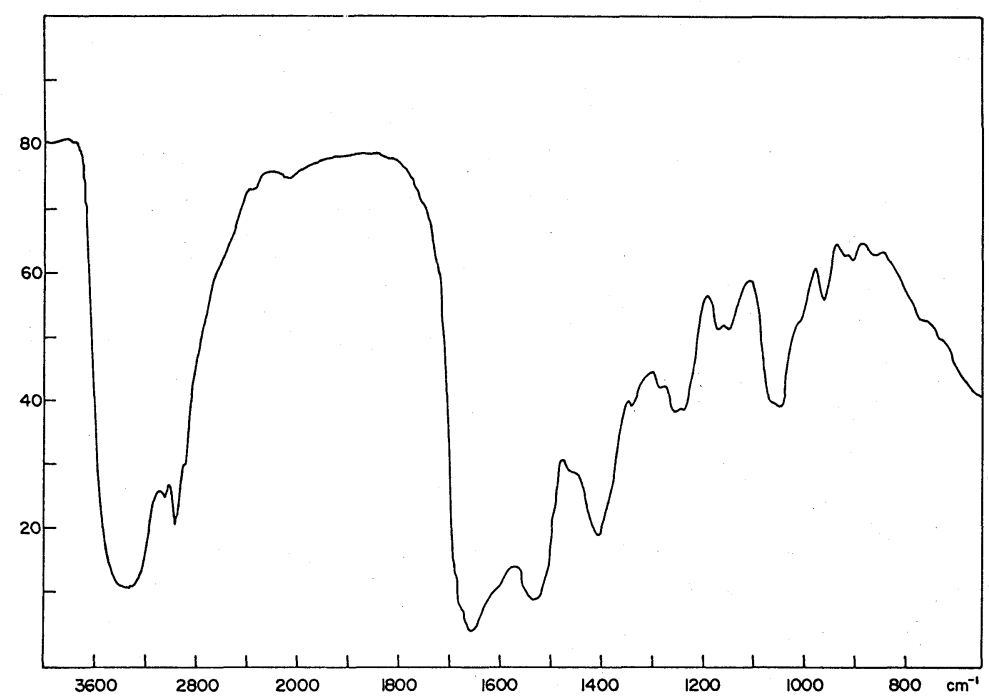

FIG. 2. IR Spectrum of Cirratiomycin A (KBr).

Table VI. ACtivity of CirRatiomycin A

Optical density $(660 \mathrm{~nm})$

\begin{tabular}{lcccccc}
\hline & \multicolumn{6}{c}{ Concentration of cirratiomycin A $(\mu \mathrm{g} / \mathrm{ml})^{*}$} \\
\cline { 2 - 7 } & 10 & 1 & 0.1 & 0.01 & 0.001 & 0.0001 \\
\hline $\begin{array}{l}\text { Lactobacillus } \\
\text { helveticus } \text { M-827 }\end{array}$ & - & 0.009 & 0.025 & 0.059 & 0.278 & 0.309 \\
$\begin{array}{l}\text { L. lactis } \text { M-908 } \\
\text { L. arabinosus }\end{array}$ & 0.008 & 0.005 & 0.371 & 0.789 & 0.825 & 0.810 \\
$\quad$ ATCC 8014 & 0.703 & 0.959 & 0.933 & 1.048 & 0.931 & 0.891 \\
$\begin{array}{l}\text { L. } \text { casei } \text { M-810 } \\
\text { Streptococcus } \\
\quad \text { lactis } \text { M-168 }\end{array}$ & 0.178 & 0.370 & 0.348 & 0.602 & 0.656 & 0.664 \\
$\begin{array}{l}\text { S. diacetylactis } 11 \mathrm{~W} \\
\quad \text { S. } \text { cremoris } \text { M-109 }\end{array}$ & 0.140 & 0.419 & 0.368 & 0.421 & 0.435 & 0.430 \\
\hline
\end{tabular}

* Assay medium was same as shown in Table IV without agar but folic acid was added (final concentration $50 \gamma /$ liter).

\section{Test-organism and medium}

The test organism used was Lactobacillus casei subsp. rhamnosus IAM 1118 which required folic acid as a growth factor. The composition of the assay medium is listed in Table IV. Activity against $L$. case $i$ was assayed by agar diffusion tests using a $6 \mathrm{~mm}$ paper disk. Because no supplement of folic acid was added to the assay medium, the test organism should have use the limited amount of folic acid which existed in the agar powder as an impurity (final concentration, $10^{-2} \gamma /$ liter). Consequently, this assay system seems to be hypersensitive to folic acid metabolites.

\section{Production and isolation}

Seed flasks were inoculated with sotck cultures of $S$. cirratus 248-Sq2 maintained at 
$-20^{\circ} \mathrm{C}$ and incubated for 48 hours at $27^{\circ} \mathrm{C}$. The seed medium consisted of $2.0 \%$ soybean meal, $2.5 \%$ dextrin, $0.5 \% \mathrm{NaCl}$ and $0.4 \%$ $\mathrm{CaCO}_{3}$ ( $\mathrm{pH}$ 6.4). Inoculum (2\%) was transferred to the production medium of the same composition and cultivated at $27^{\circ} \mathrm{C}$ for 72 hours in jar fermenters. The whole broth was filtered with the aid of $5 \%$ celite. The filtrate (50 liters) was treated with activated carbon $(1 \%)$ and the carbon cake eluted with $2 \times 10$ liters of $70 \%$ aqueous acetone $(\mathrm{pH} 3.0)$. After concentration, the eluate was applied to a column of Dowex $50 \mathrm{~W}-\mathrm{X} 2\left(7.5 \times 50 \mathrm{~cm}, \mathrm{H}^{+}\right.$ form). After being washed with water (3 liters), the column was developed with 5 liters of $5 \%$ pyridine. The active eluate was concentrated and chromatographed over a column of Dowex $50 \mathrm{~W}-\mathrm{X} 2(4.2 \times 65 \mathrm{~cm})$, which was eluted with a $0.5 \mathrm{M}$ pyridine-AcOH buffer, $\mathrm{pH}$ 6.4. The active principles were separated into two components 2 and $\mathbf{1}$ in the order of elution. These were further purified separately by repeated column chromatographies using a Sephadex G-25 partition $(3.4 \times 30 \mathrm{~cm}, n$ $\mathrm{BuOH}-\mathrm{AcOH}$-water, $4: 1: 2$ ) and Toyopearl HW $40 \mathrm{~F}(2.1 \times 100 \mathrm{~cm})$ to afford $50 \mathrm{mg}$ of 1 and $30 \mathrm{mg}$ of 2 .

\section{Physico-chemical properties}

Some physico-chemical properties are listed in Table $\mathrm{V}$. The molecular formulae of $\mathbf{1}$ and $\mathbf{2}$ were determined by the data from elemental analysis together with ${ }^{13} \mathrm{C}-\mathrm{NMR}^{1)}$ and $\mathrm{FD}$ mass spectra. The IR spectrum of 1 suggested the presence of peptide bonds in the molecules
(Fig. 2).

\section{Biological activities}

Cirratiomycin A and B are active against a narrow range of Lactobacillus including $L$. casei and some strains of Streptococcus and Mycobacterium but substantially inactive against filamentous fungi and yeasts. The activity of cirratiomycin $\mathrm{A}$ is listed in Table VI.

Acknowledgment. This work was supported in part by a Grant-in-Aid for Scientific Research from the Ministry of Education, Science and Culture of Japan.

\section{REFERENCES}

1) T. Shiroza, N. Ebisawa, K. Furihara, T. Endō, H. Seto and N. Ōtake, Agric. Biol. Chem., 46, 1891 (1982).

2) E. B. Shirling and D. Gottlieb. Intern. J. Syst. Bacteriol., 16, 313 (1966).

3) S. A. Waksman, "The Actinomycetes," Vol. 2, The Williams and Wilkins Co., Baltimore, 1961.

4) B. Becker, M. P. Lechevalier, R. E. Gordon and H. A. Lechevalier, Appl. Microbiol., 12, 421 (1964).

5) M. P. Lechevalier and H. A. Lechevalier, in $\mathrm{H}$. Prauser (ed.), "The Actinomycetales," The Jena International Symposium on Tazonomy, VEB Gustar Fischer Verlag, Jena, 1970, p. 311.

6) R. E. Buchanan and N. E. Gibbson (ed.), "Bergey's Manual of Determinative Bacteriology," 8th Ed., The Williams and Wilkins Co., Baltimore, 1974, p. 748.

7) E. B. Shirling and D. Gottlieb, Intern. J. Syst. Bacteriol., 18, 69, 279 (1968); 19, 391 (1969); 22, 265 (1972).

8) V. B. D. Skerman, V. McGowan and P. H. A. Sneath, (ed.), Intern. J. Syst. Bacteriol., 30, 225 (1980). 